\title{
Desenvolvimento de Bebida Fermentada Probiótica de Soja com Adição de Passiflora Edulis F. Flavicarpa
}

\author{
Erica Sayuri Ichimura (I), Carolina Battistini (I), Ana Maria Costa (II), \\ José Ubirajara Vieira Moreira (III), Leo Kunigk (I), Cynthia Jurkiewicz \\ Kunigk (I), Eliana Paula Ribeiro (I) \\ (I) IMT - Instituto Mauá de Tecnologia (Praça Mauá, 1 - São Caetano do Sul/SP), (II) EMBRAPA \\ Cerrados - Empresa Brasileira de Pesquisa Agropecuária (Rodovia BR-020, km 18 - Planaltina/DF), (III) \\ EMBRAPA Soja - Empresa Brasileira de Pesquisa Agropecuária (Rodovia Carlos João Strass, s/n - \\ Londrina/PR)
}

\section{Resumo}

A soja é um substituinte muito comum do leite para consumidores que apresentam restrição à ingestão de leite e derivados, devido a seu elevado teor de proteínas. A fermentação do extrato hidrossolúvel de soja por bactérias láticas e probióticas promove as características sensoriais da bebida e confere benefícios fisiológicos ao organismo. O maracujá (fruto e folha), por sua vez, é conhecido na medicina popular como calmante e hipotensor, além de ser rico em fibras. De forma a agregar os benefícios da soja e do maracujá, o objetivo deste trabalho foi desenvolver uma bebida probiótica fermentada de extrato hidrossolúvel de soja com adição de Passiflora edulis f. flavicarpa. A soja utilizada na produção do extrato hidrossolúvel de soja foi a cultivar BRS 232, desenvolvida pela Embrapa Soja, de Londrina. A massa base de P. edulis f. flavicarpa, composta pela casca e parte da polpa do fruto, foi fornecida pela Embrapa Cerrados. O processo de obtenção dos extratos consistiu nas seguintes etapas:

maceração dos grãos, cominuição, tratamento térmico em água fervente por 10 minutos, seguido de filtração, e pasteurização a $95{ }^{\circ} \mathrm{C}$ por 5 minutos. $\mathrm{Na}$ etapa de maceração foram avaliados dois tratamentos $\left(97^{\circ} \mathrm{C}\right.$ por 5 minutos e $80{ }^{\circ} \mathrm{C}$ por 2 horas) e na cominuição, três proporções mássicas de grãos de soja e água (1:9, 1:7,5 e 1:6). A massa base de Passiflora. foi adicionada ao extrato de soja após a pasteurização em proporção suficiente para que o

\footnotetext{
Referência:

Erica Sayuri Ichimura, Carolina Battistini, Ana Maria Costa, José Ubirajara Vieira Moreira, Leo Kunigk, Cynthia Jurkiewicz Kunigk, Eliana Paula Ribeiro.Desenvolvimento de Bebida Fermentada Probiótica de Soja com Adição de Passiflora Edulis F. Flavicarpa. In: Anais do 12을 Congresso Latinoamericano de Microbiologia e Higiene de Alimentos - MICROAL 2014 [= Blucher Food Science Proceedings, num.1, vol.1]. São Paulo: Editora Blucher, 2014.

DOI $10.5151 /$ foodsci-microal-035
} 
extrato apresentasse teor de fibras de 1,5\%. Para a fermentação do extrato, adicionou-se cultura, composta por Streptococcus thermophilus, Lactobacillus acidophilus e Bifidobacterium animalis, na concentração de $0,02 \%$, seguida de incubação a $37^{\circ} \mathrm{C}$, até atingir $\mathrm{pH} 4,8$. Após a etapa de fermentação, o extrato foi armazenado a $5{ }^{\circ} \mathrm{C}$ durante 29 dias. O processo que resultou em um extrato com mínimo de $3 \%$ de proteínas, exigido pela legislação vigente, foi maceração a $80^{\circ} \mathrm{C}$ por 2 horas e cominuição com proporção de 1:6 de grão e água. A fermentação do extrato foi realizada em 4 horas, alcançando acidez $(0,360 \pm 0,004) \%$. Ao final dos 29 dias, o produto apresentou $(7,1 \pm 0,4) \log \mathrm{UFC} / \mathrm{mL}$ de L. acidophilus e $(8,22 \pm$ $0,08) \log \mathrm{UFC} / \mathrm{mL}$ de B. animalis, não havendo diferença significativa quando comparado com a amostra sem adição de Passiflora. A produção do extrato hidrossolúvel de soja se mostrou viável, ao utilizar a proporção mássica soja:água de 1:6, atendendo à legislação vigente. Ao final de 29 dias de armazenamento a $5{ }^{\circ} \mathrm{C}$, o produto apresentou $10^{10} \mathrm{UFC}$ de microrganismos probióticos por porção diária de $100 \mathrm{~g}$, atendendo a legislação vigente para produtos probióticos.

Palavras-Chave: Bebida fermentada, Maracujá, Passiflora edulis f. flavicarpa, Probiótico, Soja

Agência de Fomento: 